\title{
Comparision of The Efficiency of Ethacridine Lactate and Hypochlorous Acid During the Early Period of Wound Healing in Rats
}

\author{
Yahia ALHBOU ${ }^{1}$, Birkan KARSLI ${ }^{1}$, Tuğçe SÜMER ${ }^{2}$
}

\author{
${ }^{1}$ Kirikkale University, Veterinary Faculty,Surgery Department, 71451, Kirikeale, Turkey \\ ${ }^{2}$ Kirikkale University, Veterinary Faculty,Pathology Department, 71451, Kirik,kale, Turkey
}

\begin{abstract}
The aim of this study is to compare the effects of ethacridine lactate and hypochlorous acid on wound healing in rats through clinical and histopathological studies. The rats were divided into three groups; group 1; control group, group 2; hypochlorous acid (HOCL) group, group 3; ethacridine lactate (EL) group. Each group contained seven animals. Under anesthesia, a $20 \mathrm{~mm}$ long full layer skin resection was performed from dorsal interscapular region. Wound sizes were measured with millimetric paper on the 3rd, 7th and 14th day postoperatively. At the end of the 14th day, the animals were sacrificed under deep anesthesia and extensive skin resection of the wound area was performed and sent for histopathological examination. Macroscopic examination of wounds revealed that the wound was completely closed without any crust formation in the HOCL group, and also there was only a scar left in some animals of the HOCL group at the end of 14th day. Mild inflammatory cell, intense fibroblast activity and the lowest SOD and GPx immunoreactivity were found in the HOCL group compared to the other two groups $(\mathrm{P}<0.05)$. Consequently, it was observed that macroscopically and histopathologically, the wound healing was faster in animals treated with HOCL compared to those who were in the EL and the control group.
\end{abstract}

Keywords: Ethacridine lactate, histopatology, hypochlorous acid, rat, wound healing.

\author{
$* * *$
Ratlarda Erken Dönem Yara İyileşmesinde Etakridin Laktat ve Hipokloröz Asit Etkinliğinin Karşılaştırılması
ÖZ

Bu çalışmanın amacı, etakridin laktat ve hipokloröz asidin ratlarda yara iyileşmesi üzerine etkilerinin klinik ve histopatolojik olarak karşılaştırılmasıdır. Ratlar 3 gruba ayrıldı; grup 1; kontrol grubu, grup 2; hipokloröz asid (HOCL) grubu, grup 3; etakridin laktat (EL) grubu. Her grupta 7 hayvan bulunmaktaydi. Anestezi altında, dorsal interskapular bölge derisinden $20 \mathrm{~mm}$ çapında tam katman deri rezeksiyonu yapıldı. Yara genişlikleri postoperatif 3., 7. ve 14. günlerde milimetrik kağttlarla ölçüldü. Ondördüncü gün sonunda ratlar derin anestezi altında sakrifiye edildi ve yara bölgesi rezeksiyonu yapılarak histopatolojik muayene için gönderildi. Makroskopik yara muayenesinde, 14 gün sonunda HOCL grubundaki yaraların kabuk oluşmadan kapandığı, bazı yaralarda ise sadece bir skar çizgisi olduğu görüldü. Histopatolojik incelemelerde, HOCL grubu yaralarında düşük yang1 hücresi, yoğun fibroblast varllğı ve düşük SOD ve GPx immunoreaktivitesi tespit edildi $(\mathrm{P}<0.05)$. Sonuç olarak, HOCL ile tedavi edilen hayvanlarda EL ve kontrol grubuna göre makroskopik ve histopatolojik olarak yara iyileşmesinin daha hılı gerçekleştiği görüldü.

Anahtar Kelimeler: Etakridin laktat, hipokloröz asid, histopatoloji, sıçan, yara iyileşmesi

To cite this article: Albbou Y. Karsh B. Sümer T. Comparision of The Efficiency of Ethacridine Lactate and Hypochlorous Acid During the Early Period of Wound Healing in Rats. Kocatepe Vet J. (2021) 14(3): 366-375

Submission: 04.01.2021 Accepted: 29.07.2021 Published Online: 06.09.2021

ORCID ID; Y A: 0000-0003-3891-3860, BK: 0000-0003-4208-3134, TS: 0000-0001-7033-0759

*Corresponding author e-mail: birkankarsli@gmail.com 


\section{INTRODUCTION}

Wound treatment methods have been researched for many years based on the healing and repair of the tissue (Ferguson 1988). Many healing agents are applied locally for wound treatment. Antiseptics are topical agents which are applied to living tissues and they play an important role in cleaning and/or treating open wounds and also they have ability to inhibit the proliferation of microorganisms without damage in living tissue and skin (Vissers and Winterbourn 1995). Antiseptics contain a wide range of active chemicals. While some of these substances have bacteriocydal effects, some others have bacteriostatic effects. Today, a wide range of antiseptic substances are used in wound treatment. Ethacridine lactate (EL), (Rivanol\%.1) is one of the most preferred antiseptics in wound healing for many years. In recent years, hypochlorous acid (HOCL), $0.02 \%$ has been widely used for wound treatment in humans and animals (Chai and Kim 1998).

HOCL is one of the products that arises as a result of the oxidative process produce of the neutrophils and macrophages in the immune system. HOCL is effective in wound healing and wound protection. (Marcinkiewicz et al. 2000). The neutral pH of HOCL solution gives it the properties of a safe sterilizer and an effective biocide compound. HOCL is considered as a nonirritant agent and they reduce the production of adeno triphosphate (ATP) in the bacterial cell. HOCL destroys the bacterial cell by inhibiting protein synthesis and preventing cell division and proliferation (McKenna and Davies 1988). HOCL has a wide spectrum of effects and has proven itself to be an effective agent even in the presence of biofilms on the wound (Shigeta et al. 1997). HOCL has shown to be an effective agent because of its antimicrobial, antipruritic and anti-inflammatory properties. It increases the oxygenation in wound areas (infected area) and it is also shown as an effective agent that breaks down the biofilm on the infected wound (Bongiovanni 2006). In vitro studies on antibacterial and antiviral effects of HOCL, it has been demonstrated that HOCL solution eliminates Staphylococcus aureus, Escherichia coli, Pseudomonas aeruginosa, Salmonella typhi and Candida albicans in pure culture (Zeng et al. 2010). HOCL is highly active against all bacterial, viral and fungal pathogens and a small amount of HOCL can kill spore-forming and non-spore-forming bacteria in a short time (Aratani 2006).

EL is one of the topical antiseptic agents widely used for treatment of infected wound for many years. At first it was used as an antiseptic solution, with a concentration of $1 \%$. It has been reported that EL stimulates the release of antiinflammatory cytokines (interleukin-10) during angiogenesis and formation of granulation tissue in vitro (Reinhardt et al. 2005). EL is an antibacterial and neutral medical substance that has a lethal effect on many types of bacteria. It has bactericidal effect, especially on gram-positive bacteria such as Streptococcus and Staphylococcus, while it is ineffective on gram-negative bacteria such as Pseudomonas. EL disrupts DNA synthesis by entering between the base pairs in the deoxyribonucleic acid (DNA) of bacteria. The antibacterial effects are owed to the disruption of DNA synthesis (Wainwright 2001).

The purpose of this study was to compare between ethacridine lactate and hypochlorous acid on wound healing in rat wound model through clinical and histopathological studies

\section{MATERIAL and METHOD}

The study was approved by Kirikkale University Animal Experiments Local Ethics Committee (2019/47).

\section{Animals}

In this study, 21 healthy, male, adult albino Wistar rats were used. The feed and water were given as ad libitum. Animals were divided into three groups; group 1: Control group, group 2: HOCL group, group 3: EL group. Each group contained seven animals.

Anesthesia was performed by intramuscular administration of Xylazine $(15 \mathrm{mg} / \mathrm{kg}$ ) (Rompun, Bayer, Germany) and ketamine $(100 \mathrm{mg} / \mathrm{kg}$ ) (Ketalar, Pfizer, Turkey). Dorsal interscapular region was shaved and prepared for operation (Figure 1A). The animals were placed in sternal recumbency and a full layer (dermis+epidermis) skin resection was performed with a $20 \mathrm{~mm}$ diameter punch biopsy instrument (Figure 1B). Three $\mathrm{ml}$ saline solution (0.9 $\%$ ) isotonic sodium chloride, Polifarma, Turkey) was administered to all animals via subcutan route. Flunixine meglumine were administred subcutaneously at a dose of $2.5 \mathrm{mg} / \mathrm{kg}$ for postoperative analgesia. HOCL (Crystalin spray $0.02 \%$, NHP, Turkey) was applied to the HOCL group and EL (Rivanol spray $0.1 \%$, Oro, Turkey) was applied to the EL group once a day for a period of 14 days. No medicine was used in the control group, but the animals in this group were lifted by their tails in order for them to experience the same level of anxiety as the animals of the other groups. Animals were anesthetized on the 3rd, 7th and 14th days for the purpose of measuring the wound size on the millimetric paper (Figure 2). At the end of the 14th day, the animals were sacrificed under deep anesthesia and extensive skin resection including the wound area was performed and sent for histopathological examination. 


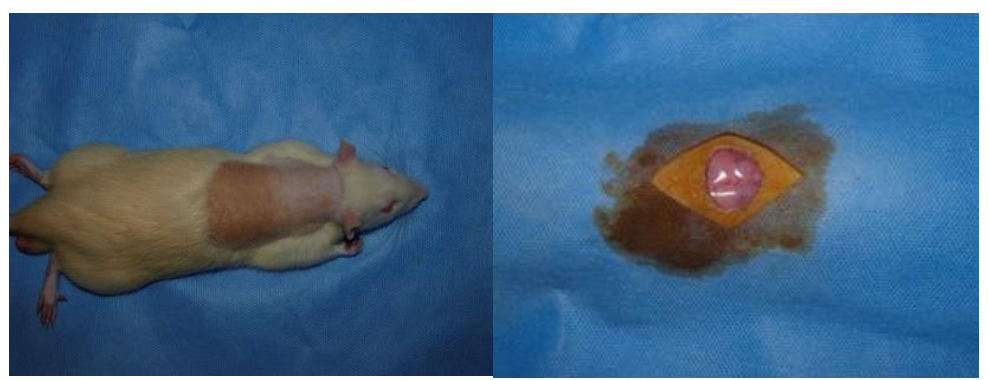

Figure 1. (A)Preoperative preparation. (B) Creation of wounds

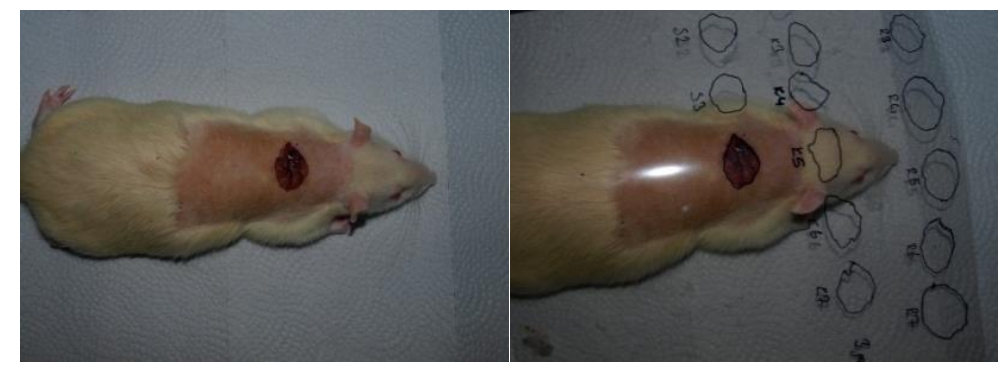

Figure 2. Drawing the wound sizes schematically for measuring with millimetric paper.

\section{Histopathologic analysis}

Tissue samples were fixed in 10\% buffered formalin and processed routinely, embedded in paraffin wax, sectioned $(4-5 \mu \mathrm{m})$ and stained with haematoxylin and eosin (HE) and Masson's trichrome (Bio Optica, Italy). The slides were examined by light microscopy (Olympus BX51, Tokyo, Japan) and digital photomicrographs were taken. Serial tissue sections were used for single and/or double-labeling immunohistochemistry. Histopathologically, the severity of inflammation, reepithelization, neovascularization and presence of fibroblast and collagen were evaluated and scored as follows (Abramov et al. 2007): Inflammatory cells 0: none, 1: 1-5 cells, 2: 6-10 cell, 3: 10-15 cells, 4: more than 15 cells. Reepithelization 0: none, 1: formation of basal layer, 2: spongiosis epidermal differentiation, 3: granular epidermal differentiation, 4: epidermal migration. Neovascularization and presence of fibroblast and collagen 0: none, 1: mild, 2: moderate, 3: severe, 4 : very severe.

\section{Immunoperoxidase test}

Immunohistochemistry was performed using a commercial immunoperoxidase kit (Thermo Scientific, USA) to demonstrate superoxide dismutase (SOD), gluthatione peroxidase (GPx), Nuclear Factor kappa B (NF- $x \mathrm{~B})$ and Inducible nitric oxide synthase (iNOS) expression in wound tissue according to the manufacturer's instructions by using diaminobenzidine $(\mathrm{DAB})$ as the chromogen and Mayer's hematoxylin as the counterstain. Normal mouse serum was used in negative control instead of primary antibody during the staining procedure. To unmask antigens, tissue sections were placed in a microwave in citrate buffer (pH: 6.0), for $20 \mathrm{~min}$ at the highest potency. Then, endogenous peroxidase activity was blocked by the use of $0,1 \%$ hydrogen peroxide in methanol for $10 \mathrm{~min}$. Protein blocking was performed for $10 \mathrm{~min}$. The sections were treated with appropriate primary antibody overnight in +4 ${ }^{\circ} \mathrm{C}$. Sections were then incubated with secondary antibody and streptavidine for $15 \mathrm{~min}$ each. Sections were treated with DAB (Thermo Scientific, USA) for 10 min and counterstained with Mayer's hematoxylin. Immunopositive reactions were evaluated according to severity of staining as follows: 0: none, 1: mild, 2 : moderate and 3: severe.

\section{Statistical Analysis}

SPSS v15 (SPSS Inc. Chicago, Illinois, America) statistical program was used in the statistical analysis of this study. The data were tested for normality using a Shapiro-Wilk test and results showed that they did not meet the parametric test assumptions. Therefore nonparametric test was used. Histopathological information and wound measurements were evaluated by nonparametric test of Kruskall-Wallis test. In cases where significance was observed, paired comparisons of the groups were determined by performing the Mann-Whitney $\mathrm{U}$ test and $\mathrm{P}<0.05$ was considered significant

\section{RESULTS}

There were no significant difference between groups for body weight $(p>0.05)$. When comparing wound diameters on the 3rd, 7th and 14th days within and between the groups, it was determined that each of them were statistically different compared to the next time point $(\mathrm{p}<0.05)$ (Table 1 and 2 ). 
When the wound healing was examined macroscopically, it was noticed that there was no difference in wound lesions on the 3rd postoperative day in all groups. While the crust formed over the wounds in the EL and control group on the 7th day, there was no crust formation in the HOCL group.
On the 14th day controls, it was observed that the wounds improved close to closure, crust formation seen on the wound in the EL group, and the wound was completely closed without the crust formation in the HOCL group, and also there was only a scar line in some animals of HOCL group (Figure 3 and 4)...

Table 1. Comparison of wound sizes $(\mathrm{mm} 2)$ in the postoperative healing period within the group

\begin{tabular}{cccc} 
Time & Control & Hypochlorous acid & Ethacridine Lactate \\
Baseline & $320,00^{\mathrm{a}}$ & $320,00^{\mathrm{a}}$ & $320,00^{\mathrm{a}}$ \\
$\mathbf{3}$ & $220 \pm 43^{\mathrm{b}}$ & $226 \pm 40^{\mathrm{b}}$ & $260 \pm 72^{\mathrm{b}}$ \\
$\mathbf{7}$ & $114 \pm 40^{\mathrm{c}}$ & $80 \pm 18^{\mathrm{c}}$ & $140 \pm 25^{\mathrm{c}}$ \\
$\mathbf{1 4}$ & $6 \pm 8^{\mathrm{d}}$ & $1 \pm 1^{\mathrm{d}}$ & $11 \pm 21^{\mathrm{d}}$ \\
P-Value $^{*}$ & $\mathrm{p} \leq 0.002$ & $\mathrm{p} \leq 0,002$ & $\mathrm{p} \leq 0,003$ \\
\hline
\end{tabular}

a,b,c,d: Differences between the groups denominated by different letters in the same coulum are significant. Data are presented as median \pm IR. 3 (postoperative 3rd day), 7 (postoperative 7th day), 14 (postoperative 14th day).

Table 2. Comparison of wound sizes $(\mathrm{mm} 2)$ between groups in the postoperative healing period

\begin{tabular}{cccc}
\hline Groups & $\mathbf{3}$ & $\mathbf{7}$ & $\mathbf{1 4}$ \\
Control & $220 \pm 43$ & $114 \pm 40 \mathrm{a}$ & $6 \pm 8 \mathrm{a}$ \\
Hypochlorous acid & $226 \pm 40$ & $80 \pm 18 \mathrm{~b}$ & $1 \pm 1 \mathrm{~b}$ \\
Ethacridine Lactate & $260 \pm 72$ & $140 \pm 25 \mathrm{c}$ & $11 \pm 21 \mathrm{a}$ \\
P-Value & $\mathrm{p}=0.22$ & $\mathrm{p} \leq 0.03$ & $\mathrm{p} \leq 0.009$ \\
\hline
\end{tabular}

a,b,c: Differences between the groups denominated by different letters in the same coulum are significant. Data are presented as median \pm IR. 3 (postoperative 3rd day), 7 (postoperative 7th day), 14 (postoperative 14th day).

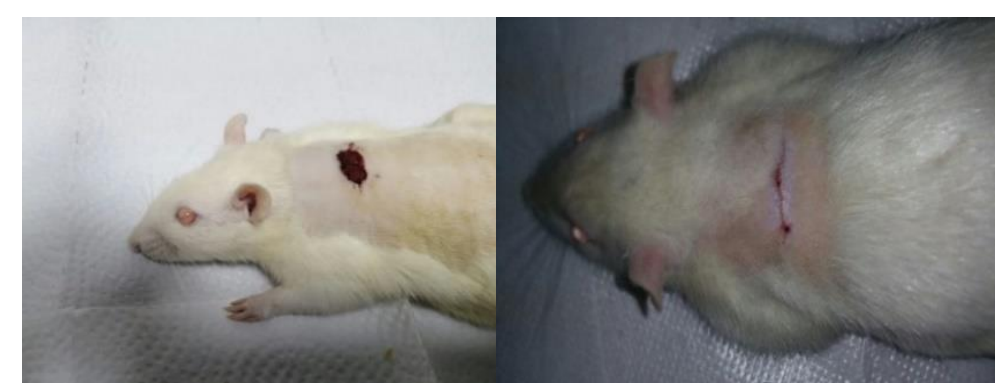

Figure 3. Macroscopic view of hypochlorous acid group wounds at 7 th and 14 th days

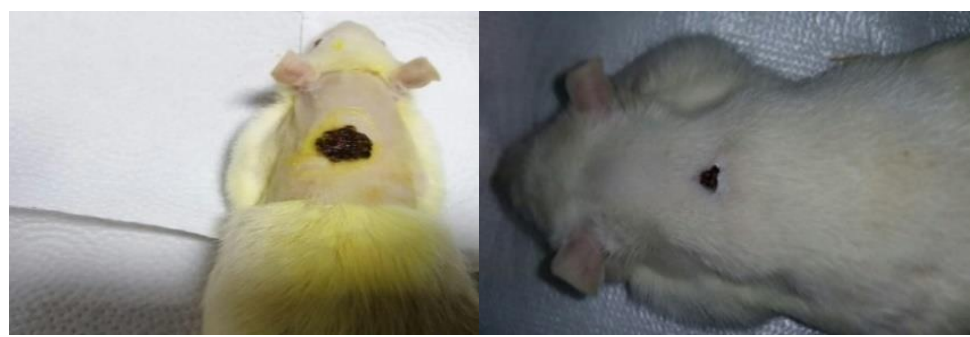

Figure 4. Macroscopic view of ethacridine lactate group wounds at 7 th and 14 th days

\section{Histopathological examination}

In the control group, there were marked infiltration of polymorph nuclear leukocytes (PMNL) and mild mononuclear cells with severe neovascularization in wound bed not covered by an epithelium (Figure 5). In HOCL group, inflammatory cells infiltration were determined but PMNL were replaced by mononuclear cells. Also there were mild to moderate collagen fibers, less neovascularization with regressed blood vessels, reepithelization characterised by keratinocytes migration and bridging of cells (Figure 6). Histopathologic findings of EL group were similar to the control group although antiseptic (ethacridine lactate) was applied on wound. In this group, necrotic debris was observed on the surface accompanied by 
inflammatory cells. The wound beds were filled with inflammatory cells rich in neutrophil leucocytes and neovascularization. Also mild new collagen fibers were (Figure 7).

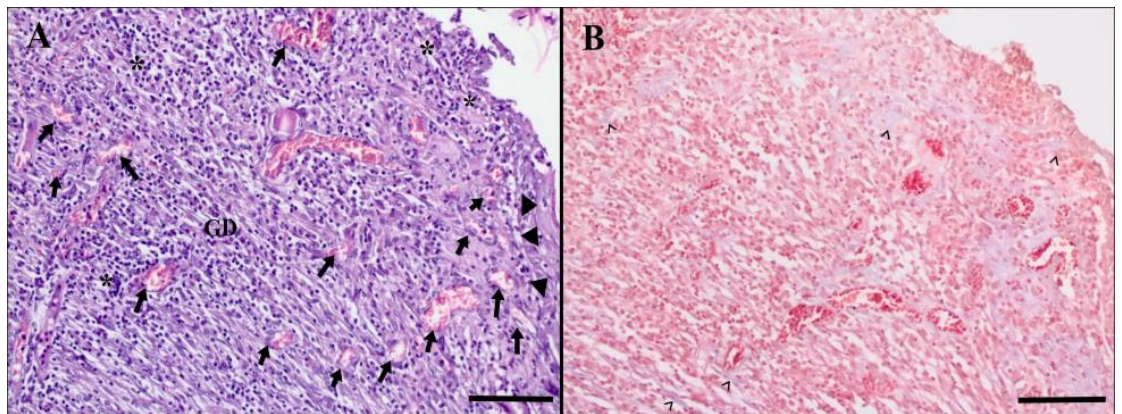

Figure 5. Control group, (A) Granulation tissue, intense neovascularization (arrow), epidermal proliferation (arrowhead), intense inflammatory cell infiltration $(*)$, Hematoxylin and Eosin (HE) staining, Bar $=60 \mu \mathrm{m}$. (B) Juvenile collagen fibers (^),Masson's Trichrome staining, Bar $=60 \mu \mathrm{m}$

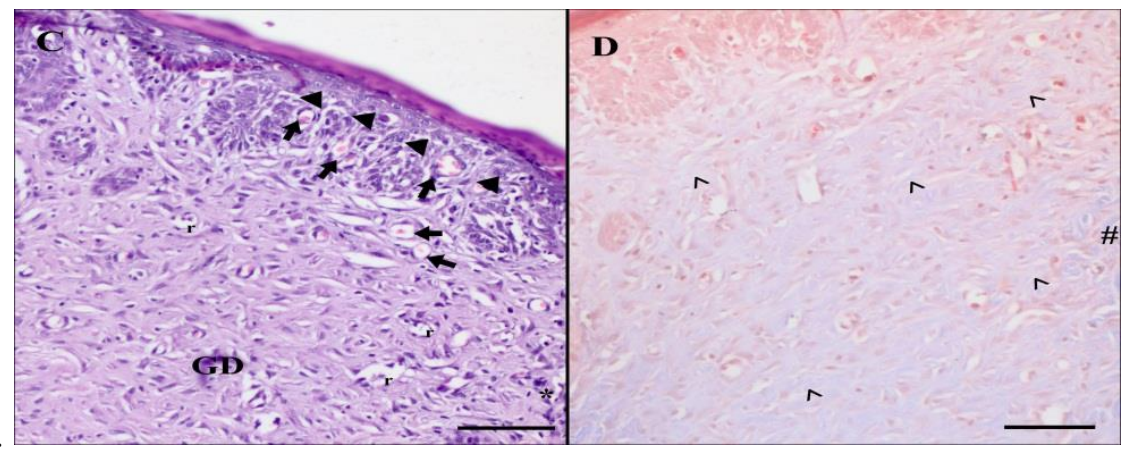

Figure 6. Hypochlorous acid group, (C) Granulation tissue, mild neovascularization (arrow), blood vessel regression (r), epidermal proliferastion (arrowhead), mild inflammatory cell infiltration $(*)$, Hematoxylin and Eosin $(\mathrm{HE})$ staining, Bar $=60 \mu \mathrm{m}$. (D) Juvenile collagen fibers $\left({ }^{\wedge}\right)$, adult collagen fibers $(\#)$,Masson's Trichrome staining, Bar $=60 \mu \mathrm{m}$.

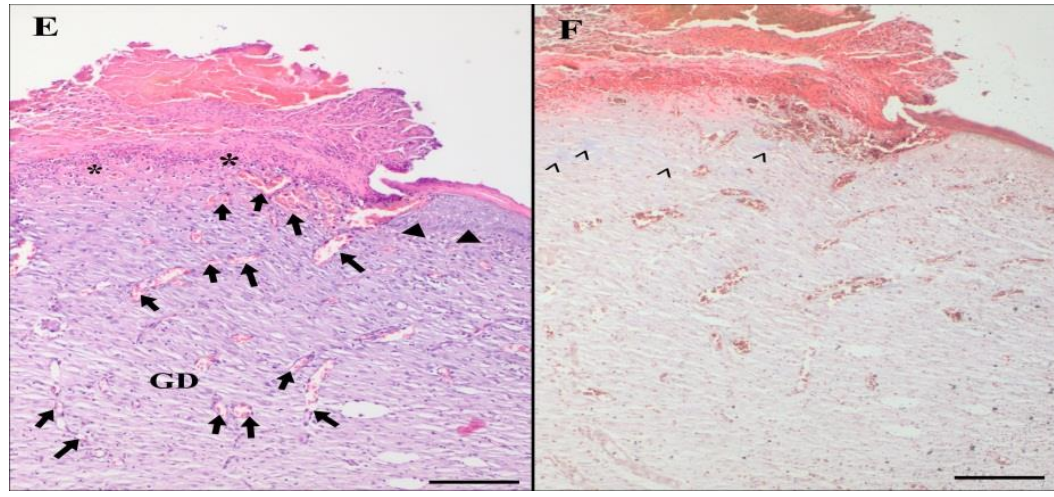

Figure 7. Ethacridine lactate group, (E) Granulation tissue, intense neovascularization (arrow), epidermal proliferation (arrowhead), intense inflammatory cell infiltration $(*)$, Hematoxylin and Eosin $(\mathrm{HE})$ staining, Bar $=100 \mu \mathrm{m}$. (F) Juvenile collagen fibers $\left(^{\wedge}\right)$,Masson's Trichrome staining, Bar $=100 \mu \mathrm{m}$.

Statistical differences were determined as a result of order to evaluate healing after sacrification $(\mathrm{p}<0.05)$ histopathological evaluation of the wound line in

Table 3. Comparision of histopathological examination results between groups

\begin{tabular}{cccccc} 
Groups & $\begin{array}{c}\text { İnflammatory } \\
\text { cell }\end{array}$ & Reepithelization & Neovaskularization & Fibroblast & Collagen \\
Control & $3 \pm 2^{\mathrm{a}}$ & $2 \pm 1$ & $3 \pm 1$ & $2 \pm 1^{\mathrm{a}}$ & $0 \pm 1$ \\
Hypochlorous acid & $2 \pm 1^{\mathrm{b}}$ & $3 \pm 1$ & $2 \pm 1$ & $3 \pm 1^{\mathrm{b}}$ & $1 \pm 1$ \\
Ethacridine Lactate & $3 \pm 1^{\mathrm{a}}$ & $2 \pm 2$ & $3 \pm 1$ & $2 \pm 0^{\mathrm{a}}$ & $1 \pm 1$ \\
P-Value & $\mathrm{p}=0.03$ & $\mathrm{p}=0.08$ & $\mathrm{p}=0.09$ & $\mathrm{p} \leq 0.03$ & $\mathrm{p}=0.06$ \\
\hline
\end{tabular}

a,b: Differences between the groups denominated by different letters in the same coulum are significant. Data are presented as median \pm IR 
All primary antibodies in all groups showed immunohistochemical reactivity, and Table 4 gave their staining intensity according to the groups. According to results, the highest GPx immunoreactivity was observed in the control group and a continuously decrease of immunopositivity was observed in EL and HOCL group. There was a statistically significant difference in Gpx values between the groups. The lowest SOD immunoreactivity was found in the HOCL group and there was a significant difference compared to the other two groups (Figure 8 and 9). It has been observed that iNOS especially in HOCL group is expressed at a moderate/severe level in both epidermal cells and newly formed young fibroblasts. However, the presence of the new iNOS expression was less in EL group and control group, respectively (Figure 10). The highest NF-kB immunopositivity was found in EL group. In EL group, moderate immunopositivity was observed in both of the newly formed epidermis and dermis, while in HOCL group, the new form of epidermis was observed in mild severity. In the control group, mild NF-kB immunopositive areas were observed in dermis (Figure

11).

Table 4. Comparision of the immunohistochemical reactivity intensity between groups

\begin{tabular}{ccccc} 
Groups & SOD & GPx & NF- $\mathbf{k}$ & iNOS \\
Control & $3 \pm 0^{\mathrm{a}}$ & $3 \pm 1^{\mathrm{a}}$ & $2 \pm 1$ & $2 \pm 1$ \\
Hypochlorous acid & $2 \pm 1^{\mathrm{b}}$ & $1 \pm 1^{\mathrm{b}}$ & $1 \pm 1$ & $2 \pm 1$ \\
Ethacridine Lactate & $3 \pm 1^{\mathrm{a}}$ & $2 \pm 0^{\mathrm{c}}$ & $2 \pm 1$ & $2 \pm 2$ \\
P-Value $^{*}$ & $\mathrm{p} \leq 0.04$ & $\mathrm{p} \leq 0.03$ & $\mathrm{P}=0.5$ & $\mathrm{P}=0.2$ \\
\hline
\end{tabular}

a,b: Differences between the groups denominated by different letters in the same coulum are significant. Data are presented as median \pm IR SOD (Superoxide dismutase), GPx (Glutathione peroxidase), NF- $x$ B (Nuclear Factor kappa B), iNOS (Inducible nitric oxide synthase

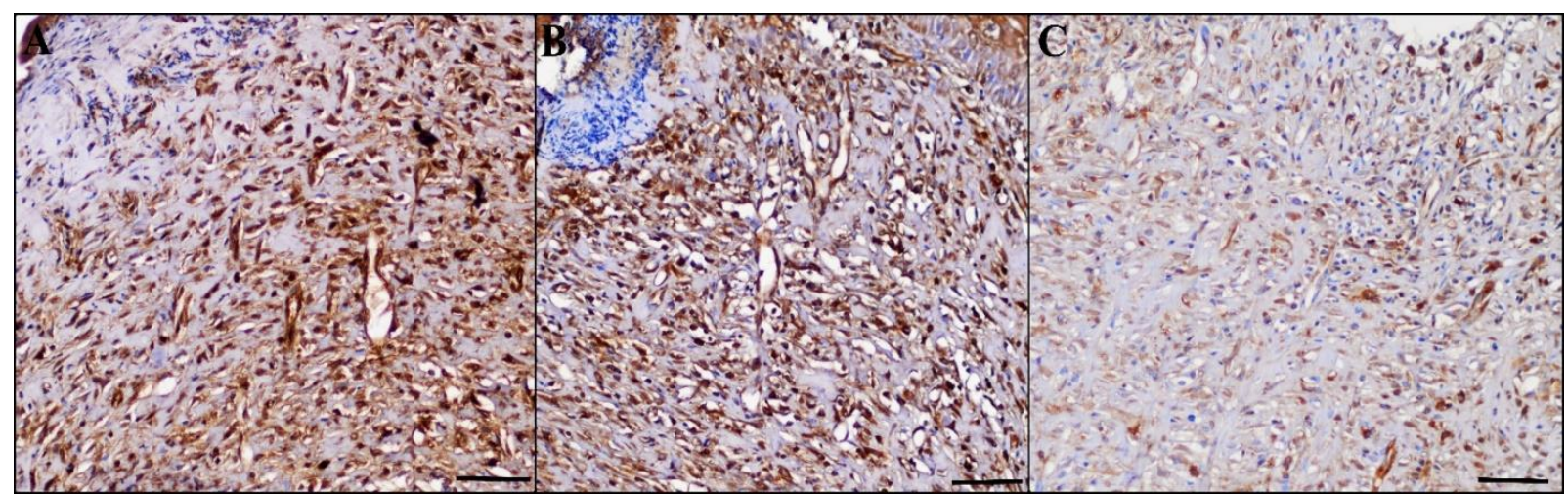

Figure 8. (A) Control group, severe SOD immunoreactivity, DAB chromogen and hematoxylin counterstain, Bar $=200 \mu \mathrm{m},(\mathrm{B})$ Ethacridine lactate group, moderate/severe SOD immunoreactivity, DAB chromogen and hematoxylin counterstain, Bar $=$ $200 \mu \mathrm{m},(\mathrm{C})$ Hypochlorous acid group, moderate SOD immunoreactivity, DAB chromogen and hematoxylin counterstain, Bar = $200 \mu \mathrm{m}$

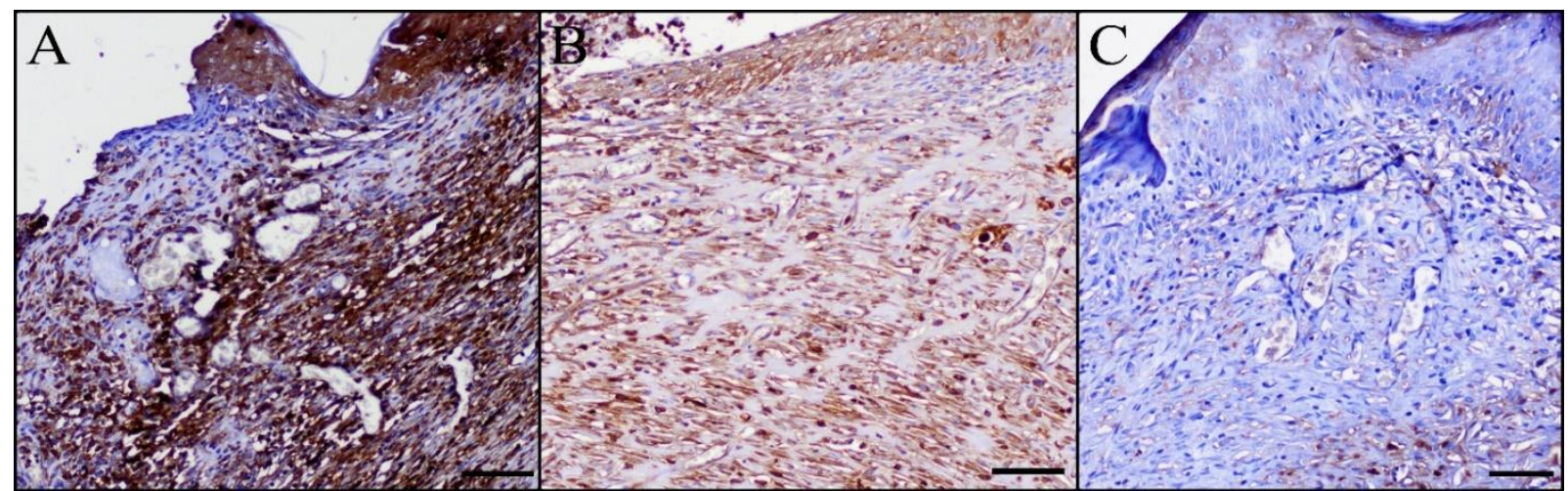

Figure 9. (A) Control group, severe GPx immunoreaktivity, DAB chromogen and hematoxylin counterstain, Bar = 200 $\mu \mathrm{m}$, (B) Ethacridine lactate group, moderate GPx immunoreaktivity, DAB chromogen and hematoxylin counterstain, Bar $=200 \mu \mathrm{m},(\mathrm{C})$ Hypochlorous acid group, mild GPx immunoreaktivity, DAB chromogen and hematoxylin counterstain, Bar $=200 \mu \mathrm{m}$ 


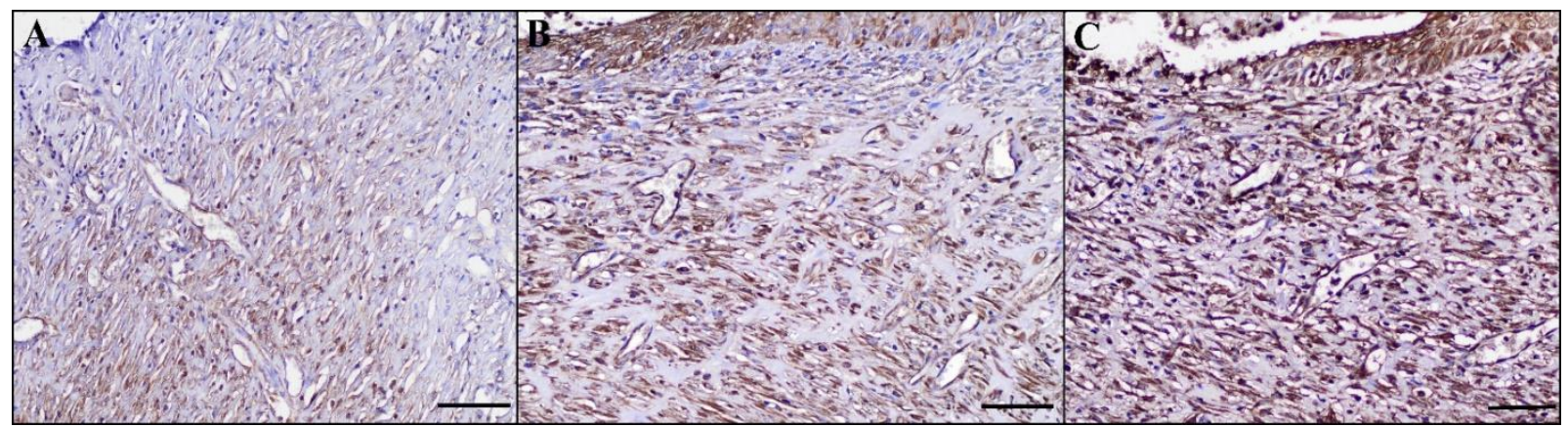

Figure 10. (A) Control group, mild iNOS immunoreaktivity, DAB chromogen and hematoxylin counterstain, Bar $=200 \mu \mathrm{m},(\mathrm{B})$ Ethacridine lactate group, moderate iNOS immunoreaktivity, DAB chromogen and hematoxylin counterstain, Bar $=200 \mu \mathrm{m}$, (C) Hypochlorous acid group, moderate/severe iNOS immunoreaktivity, DAB chromogen and hematoxylin counterstain, Bar $=200 \mu \mathrm{m}$

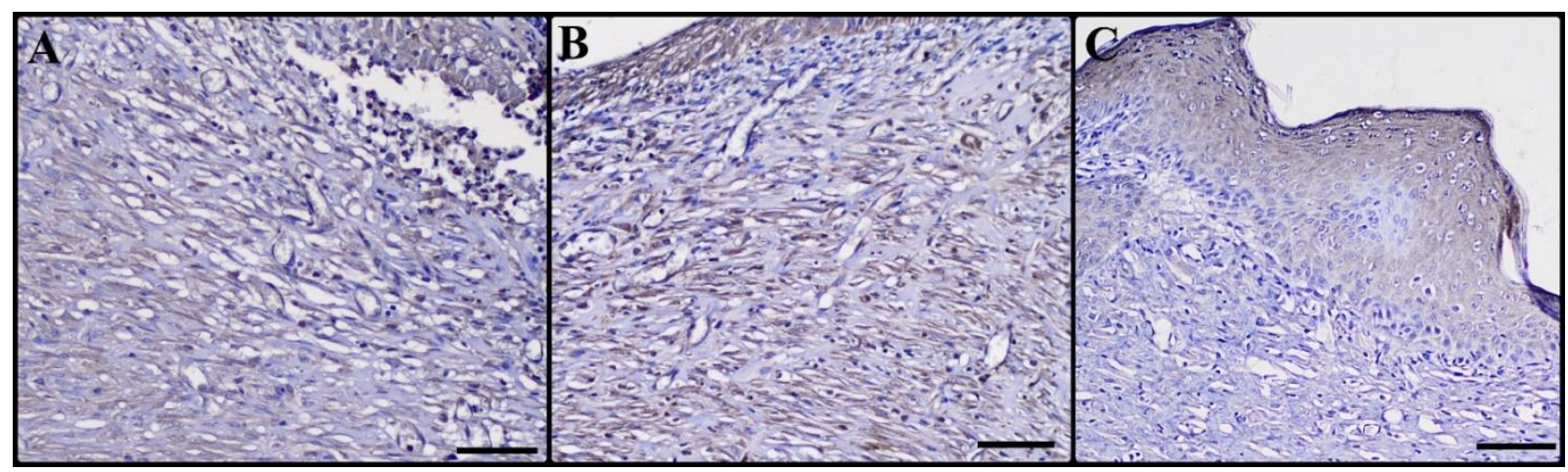

Figure 11. (A) Control group, mild NF- $x \mathrm{~B}$ immunoreaktivity, DAB chromogen and hematoxylin counterstain, Bar $=100 \mu \mathrm{m}$, (B) Ethacridine lactate group, moderate NF- $x \mathrm{~B}$ immunoreaktivity, DAB chromogen and hematoxylin counterstain, Bar $=$ $200 \mu \mathrm{m},(\mathrm{C})$ Hypochlorous acid group, mild NF- $x$ B immunoreaktivity, DAB chromogen and hematoxylin counterstain, Bar $=$ $200 \mu \mathrm{m}$

\section{DISCUSSION}

In physiological wound healing, a balance is achieved between new tissue formation and degeneration through apoptosis and reshaping of the extracellular matrix (Bucko et al. 2015). If a physiological problem occurs during the wound healing process, persistent inflammation, excessive collagen synthesis or insufficient matrix degradation and remodeling occur. As a result of these, excessive scar formation is seen in the wound (Gauglitz et al. 2011). Topical antiseptics are preferred more due to the bacterial resistance that may occur in the use of topical antibiotics on the wound, and it is reported that they are used locally to prevent infection, reduce inflammation and induce healing. Dakin solution, sodium hypochlorite $(\mathrm{NaOCl}), \mathrm{H} 2 \mathrm{O} 2$, acetic acid and povidone iodine are considered cytotoxic, although they have a broad spectrum of action against fungi and bacteria (Armstrong and Bornstein 2003, Leaper et al. 2012). It has been reported that EL which is an acridine derivative, is a non-toxic antiseptic and can be used safely in wound healing (Dale 1946). In a study, EL was used in open wounds of cats and it was reported that as a result, a moist environment was created on the wound, debridement accelerated, granulation tissue was formed and a successful cicatrization was achieved accordingly (Apaydin and Gedikli 2019). There are many studies to investigate the effect of HOCL on wound management. Easy to use, convenient, cheap, painless and safe for the treatment of infected acute traumatic wounds and providing rapid closure of surgical wounds provides an advantage over other antiseptics (Selkon et al. 2006, Gauglitz et al. 2011). It is reported that HOCL were effective in preventing scar formation on the wound. In addition, thanks to its anti-inflammatory effect, it reduces the pain and odor usually associated with wounds (Sampson and Muir 2002, Gold et al. 2017). HOCL controls bacterial density without inhibiting wound healing and it is available in spray and solution forms. (Morris 1966). It is reported that the $\mathrm{pH}$ of the wound should be less than 7.4 in order to carry oxygen from red blood cells to the wound area (Schneider et al. 2007). PH less than 6.5 provides a positive effect on wound healing. In chronic wounds, the $\mathrm{pH}$ is in the range of 7.25-8.9 (Percival et al. 2014). Previous studies have reported that the wound shrinks, epithelization accelerates, bacterial growth is inhibited and protease activity slows down at low wound pH (Gethin et al. 2008, Nagoba et al. 2017). In parallel with the previous studies, it was determined that a bacterial infection did not occur on the wound when using of neutral $\mathrm{pH}$ antiseptics, and the full layer skin wound with critical wound defect closed within 14 days. Macroscopic findings showed that the wound was completely closed in the HOCL group at the end of 14 days, and this situation was associated with better reepithelization and healing in the wound depending on the fibroblast density in the 
HOCL group. The low amount of inflammatory cells in the HOCL group and the recovery without formation of excess scar tissue at the 7 th day controls when the wound is healing are associated with antiinflammatory effect of HOCL.

Wound healing is a complex and well-regulated mechanism, and successful wound healing requires activation of three interrelated stages (inflammation, proliferation and remodeling) which are performed by platelets, leukocytes, fibroblasts and keratinocytes. Keratinocytes, which are the main cellular component of the epidermis, are very important not only for barrier formation but also for wound restoration by taking part in epithelization. Platelets facilitate homeostasis and the release of growth factors, and then leukocytes participate in the inflammatory process. Fibroblasts and keratinocytes play a critical role in wound healing by increasing reepithelization and extracellular matrix remodeling (Hynes 2009). One of the biggest advantages of using animal models in wound healing is that it provides the opportunity to follow the wound healing process histologically and also conduct macroscopic, biochemical and biomechanical measurements (Gottru et al. 2000). In many studies, many parameters such as scars, edema, fibrin coagulation, neutrophil infiltration proliferation, white blood cells, inflammatory cells such as macrophages, fibroblast proliferation, angiogenesis, granulation tissue, reepithelization and collagen proliferation in the wound were examined for histological evaluation (O’Meara et al. 2001). It is reported that a clean wound should heal or show signs of healing within two to four weeks (Monaco and Lawrence 2003). Histopathological examinations were performed to evaluate similar parameters in this study. A full layer skin wound was created and at the end of the postoperative 14th day, it was observed that the wounds healed in a similar way as explained in the literatures. Although excessive fibroblast proliferation in HOCL group, there were no statistical differences in reepithelization. However, in millimetric measurements of the wound, it is seen that the wound was closed in direct proportion to the fibroblast density in the HOCL group. When we evaluated the reepithelization values in groups, it is thought that although more reepithelialization is seen in the HOCL group, the reason for the lack of statistical difference may be related to the insufficiency in the number of animals used in the study or the fact that antiseptics, which are strong enough to damage the bacteria, damage epithelial cells (Kramer 1999).

It is reported that collagen production starts on the 7 th day in wound healing and continues until the end of the proliferation phase. During this period, the amount of collagen in the wound increases constantly. It is stated that there is a decrease in the amount of collagen with the end of the proliferation phase, and if the amount of collagen in the wound is intense at the end of this period, this situation may be related to the prolongation of the proliferative phase (Guthrie et al. 2012). In this study, there was no statistically significant difference in the amount of collagen between the groups in the histopathological examinations at the end of the 14th day, the amount of collagen was remarkably low in the control group. When a relationship was established between the excess amount of inflammatory cells and the amount of collagen in the control group, it was thought that the inflammation phase was longer in the control group and the proliferation phase started later than the other groups.

A normal wound healing consists of 4 stages; hemostasis, inflammation, proliferation and maturation and remodeling. Especially in the inflammation stage, the inflammatory cells come to the region and secrete various cytokines and reactive oxygen species (Wells et al. 2016). These reactive oxygen species directly attack and destroy pathogens in the wound area. But, excessive production of superoxide or prolongation of the inflammation phase also damages surrounding tissues. Superoxide is split into hydrogen peroxide and molecular oxygen with the help of superoxide dismutase. Hydrogen peroxide is detoxified with peroxidase such as glutathione peroxidase and catalase (Kurahashi and Fujii 2015). At this stage, the presence of superoxide dismutase and glutathione peroxidase indicates the inflammation process is ending. In this study, it was observed that SOD and GPx expressions were less in EL group and HOCL group. These expressions were especially less in HOCL group as compared to the control group at the end of the inflammatory process and the start of the proliferation phase. Healthy and young rats were used in this study. Presuming that they have a normal wound healing process, it has been observed that HOCL contributes to accelerating the wound healing process.

It is known that NF- $x \mathrm{~B}$ expression during the wound healing process increases the secretion of iNOS with proinflammatory cytokines such as interleukin-1 and interleukin-6 and plays a role in both the inflammation phase and the reepithelization phase with its proliferative effect (Jobin and Sartor 2000, Na et al. 2016). In the presented study, it was noted that although $\mathrm{NF}-x \mathrm{~B}$ immunopositivities were found in both the newly formed epithelium and epidermis in all groups, immunopositive areas in HOCL group were mostly associated with keratinocytes in the epithelial layer.

Schaffer et al. (1999) has demonstrated direct connection of collagen synthesis with iNOS expression. In the presented study, a correlation was observed between iNOS immunopositivity and the presence of collagen.

A small number of animals were used in this study, and the wound healing process was evaluated using histopathological and macroscopic data alone. Despite these limitations, wound healing was faster in HOCL group after 14 days compared to control and 
EL group. However, when we examined the physiological process, we observed that wound healing with the use of HOCL occurred within the expected time.

As a result of this study, it was observed that wound healing was performed faster in animals treated with HOCL compared to EL and control group. There was no negative effect of HOCL on wound healing. On the other hand, it has been determined that when nothing is applied to the wound or when EL is applied, wound healing may be delayed due to the long proliferation time.

Conflict of Interest: The authors declare that they have no conflict of interest.

Ethical permisson: The study was approved by Kirikkale University Animal Experiments Local Ethics Committee with the decision no. 2019/47.

Acknowledgement: This research article was summarized from Yahia ALHBOU's MSc. thesis.

\section{REFERENCES}

Abramov Y, Golden B, Sullivan M, Botros SM, Miller JJ, Alshahrour A, Goldberg RP, Sand PK (2007) Histologic characterization of vaginal surgical wound healing in a rabbit model. Wound Repair Regen. 2007;15(1):80-86.vs. abdominal

Apaydin B, Gedikli S. Wound healing effects of Nigella sativa L. essential oil in streptozotocin induced in diabetic rats. GSC Biological and Pharmaceutical Sciences. 2019;7(3):30-40.

Aratani Y. Role of myeloperoxidase in the host defense against fungal infection. Nippon Ishinkin Gakkai Zasshi. 2006;47(3):195-199.

Armstrong LC, Bornstein P. Thrombospondins 1 and 2 function as inhibitors of angiogenesis. Matrix Biology. 2003;22(1):63-71.

Bongiovanni CM. Nonsurgical management of chronic wounds in patients with diabetes. J Vasc Ultrasound. 2006;30(4):215-218

Bucko AD, Draelos Z, Dubois JC, Jones TM. A double-blind, randomized study to compare Microcyn scar management hydrogel, K103163, and Kelo-cote scar gel for hypertrophi corkeloid scars. Topical Gel for hypertrophic and keloid scars. Dermatologist. 2015;23(9):113-122.

Chai TY, Kim WB. Bactericidal Effect of Disinfectant a Superoxidized Water, Medilox. Korean J Nosocomial Infect Control. 1998;3(1):1-6.

Dale HE. Recent Development in Wound Antiseptics. Post Graduate Medical Journal. 1946; 22(246):118-121.
Ferguson A. Best Performer. Nurs Times. 1988; 84(14):52-55.

Gauglitz GG, Korting HC, Pavicic T, Ruzicka T, Jeschke MG. Hypertrophicsc arringand keloids: pathomechanisms and current and emerging treatment strategies. Molecular medicine. 2011;17(1-2):113-125

Gethin GT, Cowman S, Conroy RM. The impact of Manuka honey dressings on the surface $\mathrm{pH}$ of chronic wounds. International Wound Journal. 2008;5(2):185-194.

Gold MH, Andriessen A, Dayan SH. et al. Hypochlorous acid gel technology its impact on post procedure treatment and scar prevention. J Cosmet Dermatol. 2017; 16(2):162-167.

Gottru F, Agren MS, Karlsmark T. Models for use in wound healing research: a survey focusing on in vitro and in vivo adult soft tissue. Wound Repair Regen. 2000;8(2):83-96.

Guthrie KM, Agarwal A, Tackes DS, Johnson KW, Abbott NL, Murphy CJ, Mcanulty JF. Antibacterial efficacy of silver-impregnated polyelectrolyt emultilay ersimmobilized on a biological dressing in a murine wound infection model. Annals of surgery. 2012;256(2): 371-377

Hynes RO. The extracellular matrix: not just pretty fibrils. Science. 2009;326(5957):1216-1219.

Jobin C, Sartor RB. The I $\varkappa \mathrm{B} / \mathrm{NF}-\varkappa \mathrm{B}$ system: a key d eterminant of mucosal inflammation and protection. Am J Physiol Cell Physiol. 2000;278(3):451-462.

Kramer SA. Effect of povidone-iodine on wound healing: a review. Journal of Vascular Nursing. 1999;17(1): 17-23.

Kurahashi T, Fujii J. Roles of Antioxidative Enzymes in Wound Healing. J. Dev. Biol. 2015;3(2):57-70.

Leaper D, Ayello EA, Carville K, Fletcher J, Keast D, Lindholm C, Martinez JLL, Mavanini SD, Mcbain A, Moore Z, Opasanon S, Pina E. Appropriate use of silver dressings in wounds. Ed; MacGregor L. International Consensus Document. Wounds international, London, 2012; pp. 1-24.

Marcinkiewicz J, Chain B, Nowak B, Grabowska A, Bryniarski K, Baran J. Antimicrobial and cytotoxic activity of hypochlorous acid: interactions with taurine and nitrite. Inflamm Res. 2000;49(6):280-289.

Mckenna SM, Davies KJA. The inhibition of bacterial growth by hypochlorous acid. Possible role in the bactericidal activity of phagocytes. Biochemical J. 1998;254(3), 685692.

Monaco JL, Lawrence WT. Acute wound healing: an overview. Clinics in plastic surgery. 2003;30(1):1-12.

Morris JC. The acidionization constant of HOCL from 5 to 3.5 . The Journal of Physical Chemistry. 1966;70(12): 37983805.

Na J, Lee K, Na W, Shin JY, Lee MJ, Yune TY, Lee HK, Jung HS, Kim WS, Ju BG. Histone H3K27 demethylase JMJD3 in cooperation with NF- $x \mathrm{~B}$ regulates keratinocyte wound healing. J Invest Dermatol. 2016;136(4):847-858. 
Nagoba B, Davane M, Gandhi R, Wadher B, Suryawanshi $\mathbf{N}$, Selkar S. Treatment of skin and soft tissue infections caused by Pseudomonas aeruginosa-A review of our experiences with citric acid over the past 20 years. WoundMedicine. 2017; 19:5-9.

O'meara SM, Cullum NA, Majid M, Sheldon TA. Systematic review of antimicrobial agents used for chronic wounds. Br J Surg. 2001;88(1):4-21.

Percival SL, Mccarty S, Hunt JA, Woods EJ. The effects of $\mathrm{pH}$ on wound healing, biofilms, and antimicrobial efficacy. Wound Repair and Regeneration. 2014;22(2):174-186.

Reinhardt CS, Geske T, Schmolz M. Atopical wound disinfectant (ethacridinelactate) differentially affects the production of immune regulatory cytokines in human whole-blood cultures. Wounds. 2005;17(8):213-221.

Sampson MN, Muir AV. Not all super-oxidized water sare the same. J Hosp Infect. 2002;52(3):228-229.

Schaffer MR, Tantry U, Thornton FJ, Barbul A. Inhibition of nitric oxide synthesis in wounds: pharmacology and effect on accumulation of collagen in wounds in mice. Eur J Surg. 1999;165(3):262-267.

Schneider LA, Korber A, Grabbe S, Dissemond J. Influence of $\mathrm{pH}$ on wound-healing: a new perspective. Arch Dermatological Res. 2007;298:413-420.

Selkon JB, Cherry GW, Wilson JM, Hughes MA. Evaluation of hypochlorous acid washes in the treatment of chronic venous leg ulcers. Journal of wound care. 2006;15(1): 3337.

Shigeta M, Tanaka G, Komatsuzawa H, Sugai M, Suginaka H, Usui T. Permeation of antimicrobial agents through Pseudomonas aeruginosa biofilms: A simplemethod. Chemotherapy. 1997;43(5):340-345.

Vissers MC, Winterbourn CC. Oxidation of intracellular glutathione after exposure of human red blood cells to hypochlorous acid. Biochem J.1995; 307(1):57-62.

Wainwright M. Acridine - a neglected antibacterial chromophore. J Antimicrob Chemother. 2001;47 (1):113.

Wells A, Nuschke A, Yates CC. Skin tissue repair: Matrix microenvironmental influences. Matrix Biol. 2016;49:2536.

Zeng XP, Tang WW, Ye GQ, Ouyang T, Tian L, Yaming N, Ping L. Studies on disinfection mechanism of electrolyzed oxidizing water on E. Coli and staphylococcus aureus. J Food Sci. 2010;75(5):253-260. 